\author{
Military Technical College \\ Kobry Elkobbah, Cairo, \\ Egypt.
}

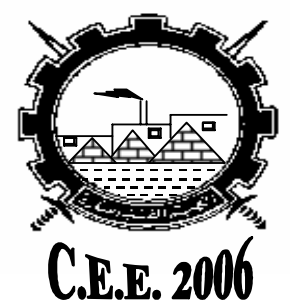

$3^{\text {rd }}$ International Conference

On

Chemical \& Environmental

Engineering

\title{
EFFECT OF CATALYST PREPARATION ON DRY REFORMING OF METHANE
}

\author{
Fakeeha A. H. ", Soliman M.A. * and Al-Fatish A. A. *
}

\begin{abstract}
In this paper the effect of changing different supports, calcination temperature and $\mathrm{Ni}$ loading on carbon dioxide reforming of methane using Ni-based catalyst are explored experimentally. The supports used are alumina (with different surface areas), silica, titania and zirconia . Calcination temperature is ranged from 773 to $1073 \mathrm{~K}$, while nickel loading is ranged from 0 to $22 \%$.The results showed that calcination at $873 \mathrm{~K}$ led to an acceptable catalyst activity. High surface area alumina proved to be the best support in terms of both activity and stability. $12 \%$ nickel loading proved to be satisfactory.
\end{abstract}

\section{KEYWORDS}

Dry reforming, Supports, Calcination temperature, Synthesis gas 


\section{INTRODUCTION}

There is a rapidly growing interest in the catalytic conversion of $\mathrm{CH}_{4}$ and $\mathrm{CO}_{2}$ to synthesis gas (Dry reforming of methane) in recent years because this reaction has many potential incentives with economical and environmental benefits [1].

The reaction proceeds according to the following equation

$$
\mathrm{CH}_{4}+\mathrm{CO}_{2} \leftrightarrow 2 \mathrm{CO}+2 \mathrm{H}_{2} \quad \Delta \mathrm{H}_{298^{\circ}}=247 \mathrm{~kJ} / \mathrm{mol}
$$

together with the following side reactions;

$$
\begin{aligned}
& \mathrm{H}_{2}+\mathrm{CO}_{2} \leftrightarrow \mathrm{CO}+\mathrm{H}_{2} \mathrm{O} \\
& \mathrm{CH}_{4} \leftrightarrow \mathrm{C}+2 \mathrm{H}_{2}
\end{aligned}
$$

Feed stock of this reaction can be obtained from waste gases e.g. ; biogas (agriculture waste, waste water treatment ), fuel gas as well as rich oil or gas field in $\mathrm{CO}_{2}$ gas,...

Dry reforming is slightly more endothermic than steam reforming. For this reason, dry reforming reaction is now being recommended for the chemical energy transmission system (CETS) to replace steam reforming. Another advantage of using dry reforming in CETS is that $\mathrm{CO}_{2}$ is commonly present in gaseous phase, so no pipe heating is needed during transportation [2-6].

Wang and Max Lu [7] studied the effects of reaction parameters on catalyst activity and carbon deposition over $\mathrm{Ni} / \gamma-\mathrm{Al}_{2} \mathrm{O}_{3}$ catalyst. They found that the reduced $\mathrm{Ni} / \gamma-$ $\mathrm{Al}_{2} \mathrm{O}_{3}$, nickel metal itself and active species of carbon were the active sites for the reaction. The carbon deposition on $\mathrm{Ni} / \gamma-\mathrm{Al}_{2} \mathrm{O}_{3}$ varied depending on the nickel loading and reaction temperature and was the major cause of catalyst deactivation and plugging of the reactor. At $5 \% \mathrm{Ni} / \gamma-\mathrm{Al}_{2} \mathrm{O}_{3}$ the catalyst exhibited high activity and much lesser magnitude of deactivation in $140 \mathrm{~h}$. The conversion increased with increasing reaction temperature and nickel content. When nickel loading was greater than $12 \mathrm{wt} \%$, the conversion would reach the thermodynamic equilibrium. They found that $\mathrm{CO}_{2}$ conversion was always higher than $\mathrm{CH}_{4}$ conversions which indicated that the reverse water gas shift reaction occurred in the $\mathrm{CO}_{2}$ reforming reaction [7].

Choudhary et al. [3] studied supported nickel catalyst prepared using commercial sintered low surface area porous catalyst carriers (containing $\mathrm{SiO}_{2}$ and/or $\mathrm{Al}_{2} \mathrm{O}_{3}$ ) pre coated with $\mathrm{MgO}, \mathrm{CaO}$ or rare-earth oxide, their results showed very much higher activity, selectivity and productivity in methane-to-syn gas conversion reaction, than the catalysts prepared using catalyst carriers without any pre coating. Among the pre coating metal oxides, the best performances was observed for $\mathrm{MgO}$.

Gadalla and Sommer [2] characterized an industrial Ni catalyst supported on $\mathrm{CaO}-$ $\mathrm{TiO}_{2}-\mathrm{Al}_{2} \mathrm{O}_{3}$ that was used for methane reforming with carbon dioxide, and compared the results with that obtained from catalyst containing $\mathrm{Ni}$ on other support. Conversion close to $100 \%$ were achieved during 51 hours on stream for a $\mathrm{CO}_{2}: \mathrm{CH}_{4}$ ratio of $2.64: 1$ using a weight hourly space velocity of $7.38 \mathrm{~h}^{-1}$ despite the solid state reaction and sintering which decrease the surface area [8]. 
Conversion of $\mathrm{CH}_{4}$ and $\mathrm{CO}_{2}$ to synthesis gas approaching those defined by thermodynamic equilibrium can be obtained over most of the aforementioned catalysts as long as contact times are kept high enough. One of the major problems encountered toward application of this process is deactivation of the catalyst by carbon deposition [9].

Suhartant et al. [10], indicated that the conversion of natural gas to liquid fuel on a commercial scale can be found in Malaysia and South Africa, although smaller demonstration plants can also be found elsewhere.

Therefore a gas - to - liquids- ( $\mathrm{GTL}$ ) process, employing $\mathrm{CO}_{2}$ reforming, offers another option for utilizing high $\mathrm{CO}_{2}$ content natural gas produced from the natural gas field.

Quincoces et al. [11] studied the effects of Mo addition on the stability, the sulfur poisoning and carbon deposition over $\mathrm{Ni}$ based catalyst for $\mathrm{CO}_{2}$ reforming of methane. The Ni catalysts promoted with small amount of Mo increases the stability of catalyst and decreases carbon deposition.

Bo-Qing xu et al. [12] studied nickel catalyst supported on $\mathrm{Al}_{2} \mathrm{O}_{3}, \mathrm{SiO}_{2}, \mathrm{TiO}_{2}$, and two $\mathrm{ZrO}_{2}$ of different preparation at $1030 \mathrm{~K}$. The activity and anti-carbon property of the nickel catalyst depend greatly on the nature of the support, while Zirconia is a good support for highly active and selective nickel catalyst. The preparation method of this support affects strongly the catalyst stability.

Potdar et. al. [13 ] prepared catalysts composed of $\mathrm{Ni}-\mathrm{Ce}-\mathrm{ZrO}_{2}$ by one step coprecipitation technique. Their results indicate the superiority of technique in comparison with the impregnation technique having the same composition. Using $15 \% \mathrm{Ni}\left(\mathrm{w} / \mathrm{w}\right.$ ) co-deposited with $\mathrm{CeZrO}_{2}$ gave catalyst that had a yield of $97 \% \mathrm{CH}_{4}$ conversion at $800{ }^{\circ} \mathrm{C}$ and the activity was maintained for $100 \mathrm{hr}$, this indicated that the reason for this superiority is due to the nano-crystalling nature of cubic $\mathrm{Ce}_{1-\mathrm{x}}-\mathrm{Zr} \times \mathrm{O}_{2}$ producing strong interaction with finely dispersed nano-sized $\mathrm{NiO}_{\mathrm{x}}$ crystallizes

It is noticed that the previous studies differ in preparation methods, calcination temperatures, activation procedure, catalyst loading and or reaction temperature. This paper present experimental study that explore the effect of using different supports (Alumina , Silica, Titania, and Zirconia ), calcinations temperature and nickel loading on the performance of $\mathrm{Ni}$ - based supported catalysts for dry reforming reaction.

\section{EXPERIMENTAL}

\section{Preparation method:}

Different supports have been used to prepare $\mathrm{Ni}$ - base supported catalysts. The supports used are high surface area alumina[ $\gamma$-alumina (SA-6175)], low surface area alumina [ $\alpha$-alumina (SA-5239)], medium surface area alumina (SN-74707) silica (S151-10), $\mathrm{TiO}_{2}$, and $\mathrm{ZrO}_{2}$ the surface area of the above supports are $(230-290$ $\left.\mathrm{m}^{2} / \mathrm{gm}\right),\left(0.15-0.45 \mathrm{~m}^{2} / \mathrm{gm}\right),\left(80-120 \mathrm{~m}^{2} / \mathrm{gm}\right),\left(<1 \mathrm{~m}^{2} / \mathrm{gm}\right),\left(11.8 \mathrm{~m}^{2} / \mathrm{gm}\right),(6.9$ $\mathrm{m}^{2} / \mathrm{gm}$ ) respectively. Impregnation of the supports was carried out with aqueous solutions of nickel-nitrate. After impregnation, the catalysts were dried for $13 \mathrm{hr}$. at $383 \mathrm{~K}$ and calcined for $5 \mathrm{hr}$ at $873^{\circ} \mathrm{K}$ in air atmosphere. 


\section{Experimental set-up:}

The experimental equipment used in this study is AMI- 2000 ZETON-ALTAMIRA micro-reactor system which is shown schematically in Fig. 1. The system is composed of the following sections:

1. Feed Section: The feed section contains three gas cylinders for $\mathrm{CO}_{2}, \mathrm{CH}_{4}$ and $\mathrm{N}_{2}$. Gases coming from the regulators pass through in-line filters are then introduced to the Mass Flow Controllers (MFC), obtained from Brooks. The gases are mixed and passed to the reaction section. On line samples from the feed gas mixture are directed to gas chromatograph for analysis.

2. Reaction Section: The micro-reactor overall length is $0.43 \mathrm{~m}$, with inside diameter of $6.35 \times 10^{-3} \mathrm{~m}$ made of stainless steel and surrounded by three zones heater. Each zone temperature can be controlled separately. The temperature in the reactor is measured by a thermocouple located at three different location along the reactor height. The outlet from the reactor (bottom end) is passed through a back pressure regulator (BPR) to control the pressure in the reactor and the sample of product gases from the BPR were sent to analysis section .

3. Analysis Section : 3400-CX Varian gas chromotograph with TDC detector was used. The detector is equipped with Haysep A column.

\section{Activation procedure}

This pretreatment process was found to be essential for the reaction to take place.

The activation procedure was carried out according to the following:

A. Introduce hydrogen to the reactor at $20 \mathrm{ml} / \mathrm{min}$ for $2.5 \mathrm{hr}$.

B. Then hydrogen is stopped while $\mathrm{N}_{2}$ is introduced at $40 \mathrm{ml} / \mathrm{min}$ for one hour.

Comparing catalyst $\mathrm{A} 2$ which was activated with catalyst $\mathrm{A} 1$ that was not activated, the conversion of both $\mathrm{CH}_{4}$ and $\mathrm{CO}_{2}$ as well as $\mathrm{H}_{2}$ yield for the activated catalyst is much higher than the unactivated catalyst as shown in table (1)

Table 1: Conversion and yield with activated and unactivated catalyst

\begin{tabular}{|c|c|c|}
\hline & Activated catalyst & unactivated catalyst \\
\hline \hline Conversion of $\mathrm{CH}_{4}$ & 34.7 & 2.51 \\
\hline Conversion of $\mathrm{CO}_{2}$ & 35.1 & 5.11 \\
\hline $\mathrm{H}_{2}$ yield & 31.4 & 1.1 \\
\hline
\end{tabular}

\section{RESULTS AND DISCUSSION}

\section{Effect of the supporting material}

The six different types of supports used were prepared at two different calcinations temperature 773 and $1073 \mathrm{~K}$ and tested at $773,823,848 \mathrm{~K}$. The results are presented in Fig. 2-5 and Tables 2-4 for conversion of $\mathrm{CH}_{4}$. The results for most of 
the catalysts prepared showed increased in conversion with the increased in tested temperature. Different supports gave different results at different calcination temperatures. The results for some catalysts prepared with calcinations temperature at $773 \mathrm{~K}$ is better than that obtained with catalyst prepared at calcinations temperature of $1073 \mathrm{~K}$. It is noticed that when $\mathrm{Zr}$-Oxide was used as support methane conversion is very low for catalysts prepared at both calcinations temperature used, so it will be excluded from further studies. No conclusive choice for the best support can be drawn from these results (conversion), so stability tests were conducted for all catalysts prepared and the results are shown in Table 5 . Alumina with high surface area (SA-6175) shown high stability for $86 \mathrm{~h}$ as can be seen in Fig. 6 while the other catalyst prepared with other support show deactivation and or agglomeration so high surface area alumina will be selected for further studies.

\section{Effect of the Nickel Loading}

Fig. 7 show the effect of increasing nickel loading from $0-22 \%$ on $\mathrm{CH}_{4}$ conversion. The results show that as temperature and nickel content increases the $\mathrm{CH}_{4}$ conversion increases up to $12 \%$ then slight increase occur which indicate that equilibrium was almost reached. At $22 \%$ nickel loading, the catalyst agglomerate, similar results obtained for $\mathrm{CO}_{2}$ conversion and hydrogen yield

\section{Effect of the calcination temperature:-}

Several catalysts supported on high surface area alumina were prepared using nickel loading of $12 \%$ and calcined at $773,873,923,973,1073 \mathrm{~K}$ Testing these catalysts at atmospheric pressure and $773,823,848 \mathrm{~K}$ indicated that both $\mathrm{CH}_{4}$ and $\mathrm{CO}_{2}$ conversion decreased as calcination temperature increased above $873 \mathrm{~K}$. At $773 \mathrm{~K}$ the conversion of $\mathrm{CH}_{4}$ at the above selected calcinations temperatures are $(17.1 \%, 16.4 \%, 14 \% 1.3 \%, 0.61 \%)$, while the conversion of $\mathrm{CO}_{2}$ at the above selected calcinations temperatures are $(23.7 \%, 23.7 \%, 23.4 \% 2.8 \%, 1.1 \%)$ respectively Fig. (8) is sample of these results for conversion of $\mathrm{CO}_{2}$. The results indicated increasing temperature above $873 \mathrm{~K}$ is not desirable.

\section{CONCLUSION}

From this experimental study the following conclusions can be drawn:

1. High surface alumina is the best support among the supports tested in our study

2. Calcination at $873 \mathrm{~K}$ is recommended

3. $12 \%$. Nickel loading is quite satisfactory

\section{ACKNOWLEDGMENT}

The authors would like to thank Deanship of Research and Research center at College of Engineering as well as SABIC Company for financial assistance of this work. 


\section{REFERENCES}

[1] Chen , Y.G., Tomishige , K. , Yokoyama, K., Fajimoto , Y.K. , " Promoting effect of $\mathrm{Pt}, \mathrm{Pd}$ and $\mathrm{Rh}$ noble metals to the $\mathrm{Ni} 0.03 \mathrm{MgO} 0.97$ solid solution catalyst for the reforming of $\mathrm{CH} 4$ with CO2" , Appl. Catal. A: Genera , No. 165, pp 335-347, (1997).

[2] Bradford M.C.J., and Vannice, M.A., Carbon dioxide reforming of methane over supported Pt catalysts, J. Catal.,No.173, pp.157, (1998).

[3] Choudhary, V.R., and Mamman, A.S., Simultaneous oxidative conversion and carbon dioxide or steam reforming of methane to syngas over CoO-NiO-MgO catalysts , J. Chem. Technol. Biotechnical , 73,pp 345, (1998) .

[4] Osaki, T., Horiachi, T., Suzuki, K, Mori, T. ,Suppression of carbon deposition in Carbon dioxide reforming of methane on metal sulphide catalyst, Catal. Lett., No.35, pp.39, (1995).

[5] Sakai, Y., Satio, H., Sodesawa T., Nozaki, F., "Catalytic reactions of hydrocarbon with carbon dioxide over metallic catalysts.", Catal. Lett., No.24, pp.253, (1984).

[6] Swan, H., OKroll, V., Martin and G., Mirodatos,C., Deactivation of supported nickel catalysts during the reforming of methane by carbon dioxid, Catalysis Today, No.21, pp.571, (1994).

[7] Wang , S., and Max Lu, G.O, J. Chem. Techn. Biotechnol, " Effect of prmoters on catalytic activity and carbon deposition $\mathrm{Ni} / \mathrm{Y}-\mathrm{Al} 2 \mathrm{O} 3$ catalyst in $\mathrm{CO} 2$ reforming of CH4, No.75,PP589-595, (2000).

[8] Gadalla, A.M., and Sommer, M.E., Carbon dioxide reforming of methane on Nickle catalys, Chem. Eng. Sci., 1 No.44, pp.2825, (1989).

[9] Zhung,Z.L., Tsipouyiari,V.A., Verykios, X.E., Reforming of methane with carbon dioxide to synthesis gas over supported Rhodium catalyst, J. Catal., No.158, pp.51, (1996).

[10] Suhartant,T., York, P.E.A., A. Hanif, A., Al-Megren H., Green L.H.M., Potential utilization of Indonesian Natuna natural gas field via methane dry reforming to synthesis gas", Catal. Lett., No.71, pp.49, (2001).

[11] Quincoces,C.E., Perez, S., Gonzales, M.G., carbon dioxide reforming of methane over Mo promoted Nickel-based catalysts, Studies in Surface Science and Catalysts, pp.130, (2000).

[12] Xu , Bo- Qing, Wei ,J.M., Wang H.Y., Sun,K.,Zhu,Q., Nano-Mgo: noval preparation and application as support of $\mathrm{Ni}$ catalyst for $\mathrm{CO}_{2}$ reforming of methane, Catalysis Today, No. 68, pp.217, (2001).

[13] Potdar, H.S., ROH,H., June,K.W.,Jr. M.,Liue,Z., Carbon dioxide reforming of methane over co- precipitated Ni-Ce-ZrO2 Catalyst, Catal. Lett. , No.84, pp 95, (2002). 
Table 2: conversion of $\mathrm{CH} 4, \mathrm{CO}_{2}$ and hydrogen yield using catalyst with different supports calcined at $773,1073^{\circ} \mathrm{K}$ and tested at $773^{\circ} \mathrm{K}$

\begin{tabular}{|c|c|c|c|c|c|c|c|c|c|c|c|c|}
\hline \multirow{2}{*}{$\begin{array}{c}\text { Support } \\
\text { Calcination }{ }^{\circ} \mathrm{K}\end{array}$} & \multicolumn{2}{|c|}{ SA-6175 } & \multicolumn{2}{|c|}{ SN-74707 } & \multicolumn{2}{|c|}{ SA-5239 } & \multicolumn{2}{|c|}{$S 151-10$} & \multicolumn{2}{|c|}{ Zr-Oxid } & \multicolumn{2}{|c|}{$\mathrm{TiO}_{2}$} \\
\hline & 773 & 1073 & 773 & 1073 & 773 & 1073 & 773 & 1073 & 773 & 1073 & 773 & 1073 \\
\hline Conversion $\mathrm{CH}_{4}$ & 17.2 & 0.61 & 20 & 18.1 & 31.6 & 39.8 & 12.2 & 24.1 & 0.13 & 1.12 & 18.4 & 25.1 \\
\hline Conversion $\mathrm{CO}_{2}$ & 22.7 & 1.1 & 20.4 & 27.1 & 17.4 & 19.2 & 18.4 & 18.3 & 0.83 & 2.8 & 19.9 & 15.4 \\
\hline Hydrogen yield & 16.1 & 0.32 & 17.6 & 16.9 & 25.9 & 30.0 & 11.6 & 21.3 & 0.08 & 0.27 & 16.35 & 22.9 \\
\hline
\end{tabular}

Table 3 : conversion of $\mathrm{CH}_{4}, \mathrm{CO}_{2}$ and hydrogen yield using catalyst with different supports calcined at $773,1073{ }^{\circ} \mathrm{K}$ and tested at $823^{\circ} \mathrm{K}$

\begin{tabular}{|c|c|c|c|c|c|c|c|c|c|c|c|c||}
\hline \multirow{2}{*}{$\begin{array}{c}\text { Support } \\
\text { Calcination }\end{array}{ }^{\circ} \mathrm{K}$} & \multicolumn{2}{|c|}{ SA-6175 } & \multicolumn{2}{|c|}{ SN-74707 } & \multicolumn{2}{|c|}{ SA-5239 } & \multicolumn{2}{|c|}{ S151-10 } & \multicolumn{2}{c|}{ Zr-Oxid } & \multicolumn{3}{c|}{ TiO $_{2}$} \\
\cline { 2 - 13 } & $\mathbf{7 7 3}$ & $\mathbf{1 0 7 3}$ & $\mathbf{7 7 3}$ & $\mathbf{1 0 7 3}$ & $\mathbf{7 7 3}$ & $\mathbf{1 0 7 3}$ & $\mathbf{7 7 3}$ & $\mathbf{1 0 7 3}$ & $\mathbf{7 7 3}$ & $\mathbf{1 0 7 3}$ & $\mathbf{7 7 3}$ & $\mathbf{1 0 7 3}$ \\
\hline \hline Conversion & 34.7 & 1.83 & 40.0 & 34.3 & 45.4 & 58.9 & 22.1 & 40.7 & 0.26 & 1.84 & 43.4 & 47.7 \\
\hline Conversion $\mathrm{CO}_{2}$ & 35.1 & 3.4 & 39.0 & 40.1 & 28.3 & 30.5 & 30.2 & 32.7 & 1.6 & 1.6 & 30.2 & 27.3 \\
\hline Hydrogen yield & 31.4 & 0.93 & 35.4 & 31.4 & 46.9 & 46.7 & 20.5 & 36.0 & 0.17 & 0.50 & 38.0 & 41.5 \\
\hline
\end{tabular}


Table 4: conversion of $\mathrm{CH}_{4}, \mathrm{CO}_{2}$ and hydrogen yield using catalyst with different supports calcined at $773,1073^{\circ} \mathrm{K}$ and tested at $848^{\circ} \mathrm{K}$

\begin{tabular}{|c|c|c|c|c|c|c|c|c|c|c|c|c||}
\hline \multirow{2}{*}{$\begin{array}{c}\text { Support } \\
\text { Calcination }\end{array}$} & \multicolumn{2}{|c|}{ SA-6175 } & \multicolumn{2}{|c|}{ SN-74707 } & SA-5239 & \multicolumn{2}{c|}{ S151-10 } & \multicolumn{2}{c|}{ Zr-Oxid } & \multicolumn{3}{c|}{ TiO $_{2}$} \\
\cline { 2 - 13 } & $\mathbf{7 7 3}$ & $\mathbf{1 0 7 3}$ & $\mathbf{7 7 3}$ & $\mathbf{1 0 7 3}$ & $\mathbf{7 7 3}$ & $\mathbf{1 0 7 3}$ & $\mathbf{7 7 3}$ & $\mathbf{1 0 7 3}$ & $\mathbf{7 7 3}$ & $\mathbf{1 0 7 3}$ & $\mathbf{7 7 3}$ & $\mathbf{1 0 7 3}$ \\
\hline \hline Conversion $\mathrm{CH}_{4}$ & 46.2 & 2.2 & 50.0 & 47.5 & 63.5 & 64.7 & 22.5 & 47.6 & 0.33 & 2.53 & 58.0 & 58.0 \\
\hline Conversion $\mathrm{CO}_{2}$ & 43.0 & 4.64 & 47.6 & 44.0 & 40.1 & 41.9 & 31.6 & 42.6 & 2.9 & 6.10 & 35.7 & 38.2 \\
\hline Hydrogen yield & 43.04 & 0.89 & 45.8 & 43.6 & 54.6 & 54.0 & 20.4 & 44.0 & 0.24 & 0.78 & 51.5 & 52.0 \\
\hline
\end{tabular}

Table 5 . Comparison of conversions for both $\mathrm{CH}_{4} \& \mathrm{CO}_{2}$ as well as hydrogen yield during the stability studies

\begin{tabular}{|c|c|c|c|c|c|c|c|c|c|c|c|}
\hline \multirow{2}{*}{ Support } & \multicolumn{2}{|c|}{$\mathrm{CH}_{4}$ conversion } & \multicolumn{2}{|c|}{$\mathrm{CO}_{2}$ conversion } & \multicolumn{2}{|c|}{$\mathrm{H}_{2}$ yield } & \multicolumn{2}{|c|}{$\mathrm{H}_{2} / \mathrm{CO}$} & \multicolumn{2}{|c|}{ Time on stream } & \multirow{2}{*}{ Remarks } \\
\hline & First & End & Start & End & Start & End & Start & End & & & \\
\hline$\underline{\text { SA-6175 }}$ & 16.9 & 16.1 & 26.2 & 25.8 & 15.3 & 15.3 & 0.60 & 0.61 & 86 & $\mathrm{~h}$ & Stable \\
\hline SN-74707 & 17.4 & 16.3 & 25.3 & 24.9 & 15.6 & 15.2 & 0.63 & 0.61 & 58 & $\mathrm{~h}$ & Slightly agglomeration \\
\hline SA-5239 & 24.6 & 6.5 & 17.5 & 11.6 & 21.5 & 5.2 & 1.42 & 0.45 & 31 & $\mathrm{H}$ & $\begin{array}{l}\text { Deactivation(black carbon \& } \\
\text { agglomerate) }\end{array}$ \\
\hline S151-10 & 7.03 & 1.8 & 13.0 & 5.3 & 6.5 & 1.47 & 0.51 & 0.28 & 13 & $\mathrm{H}$ & $\begin{array}{l}\text { Deactivation(black carbon \& } \\
\text { agglomerate) }\end{array}$ \\
\hline $\mathrm{TiO}_{2}$ & 17.6 & 8.9 & 24.7 & 14.4 & 15.4 & 7.7 & 0.65 & 0.55 & 55 & $\mathrm{H}$ & $\begin{array}{l}\text { Deactivation(black carbon \& } \\
\text { agglomerate) }\end{array}$ \\
\hline
\end{tabular}




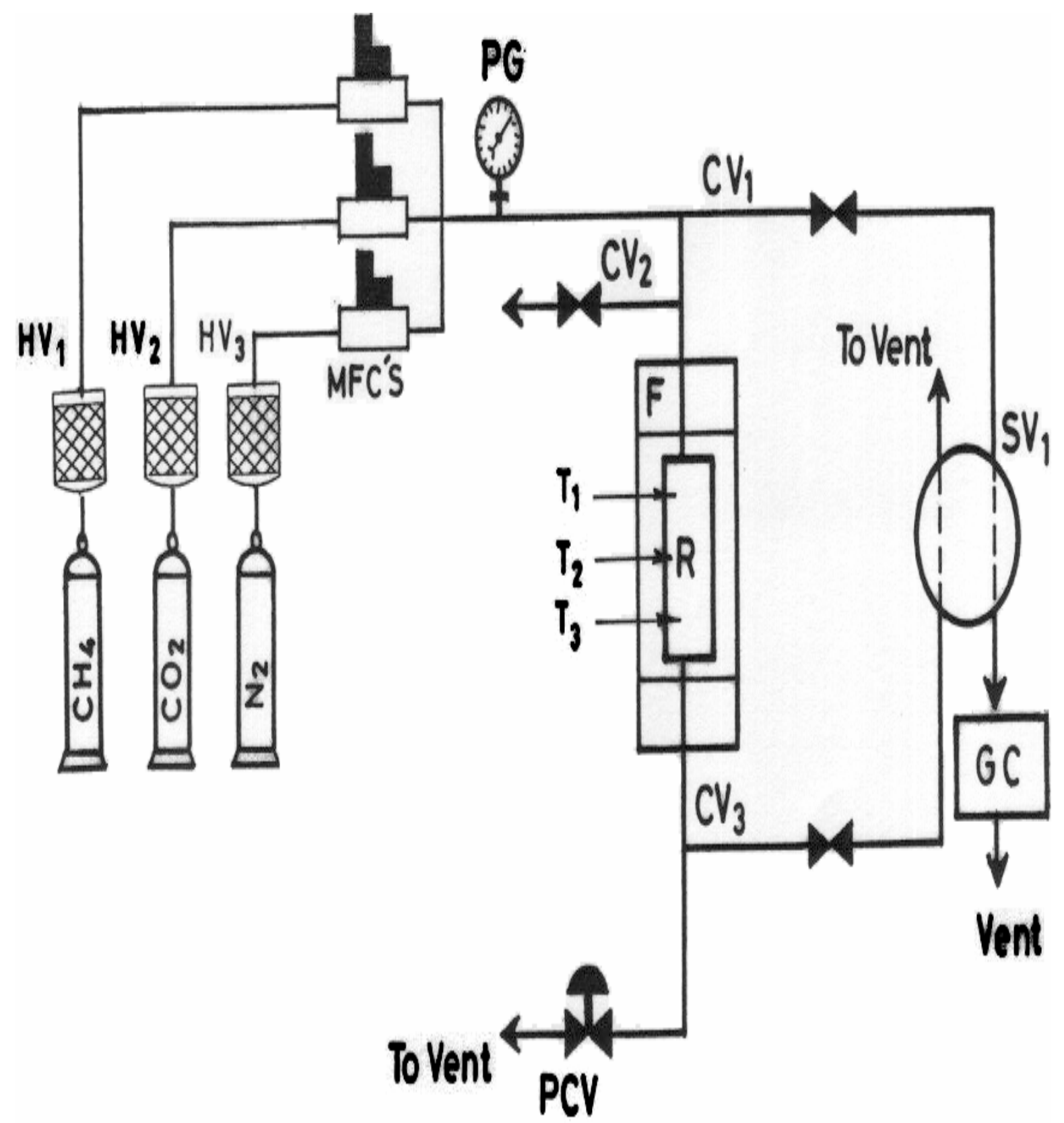

Figure 1: Schematic of experimental setup. $\left(\mathrm{HV}_{1}, \mathrm{HV}_{2}\right.$ and $\mathrm{HV}_{3}$ Filters, MFC's Mass Flow Controller, PG Pressure Gauge $\mathrm{CV}_{1}, \mathrm{CV}_{2}$ and $\mathrm{CV}_{3}$ Shut-off Valves, $\mathrm{SV}_{1}$, Sampling Valve, $F$ Furnace, $R$ Reactor, $T_{1}, T_{2}, T_{3}$ Temperature Measurement (by Thermocouple), GC, Gas Chromatograph, PCV, Pressure Control Valve.) 


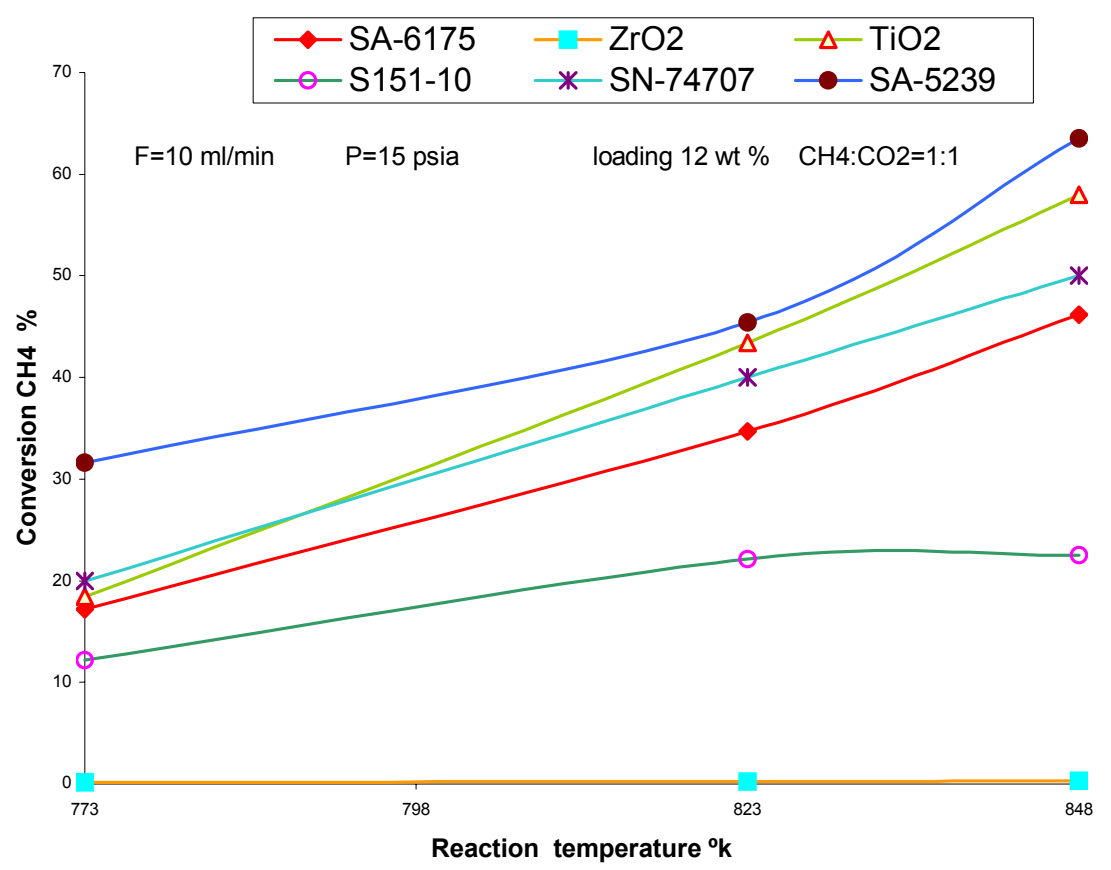

Figure 2. Effect of different types of supports on $\mathrm{CH} 4$ conversion at calcination temperature of $773^{\circ} \mathrm{k}$

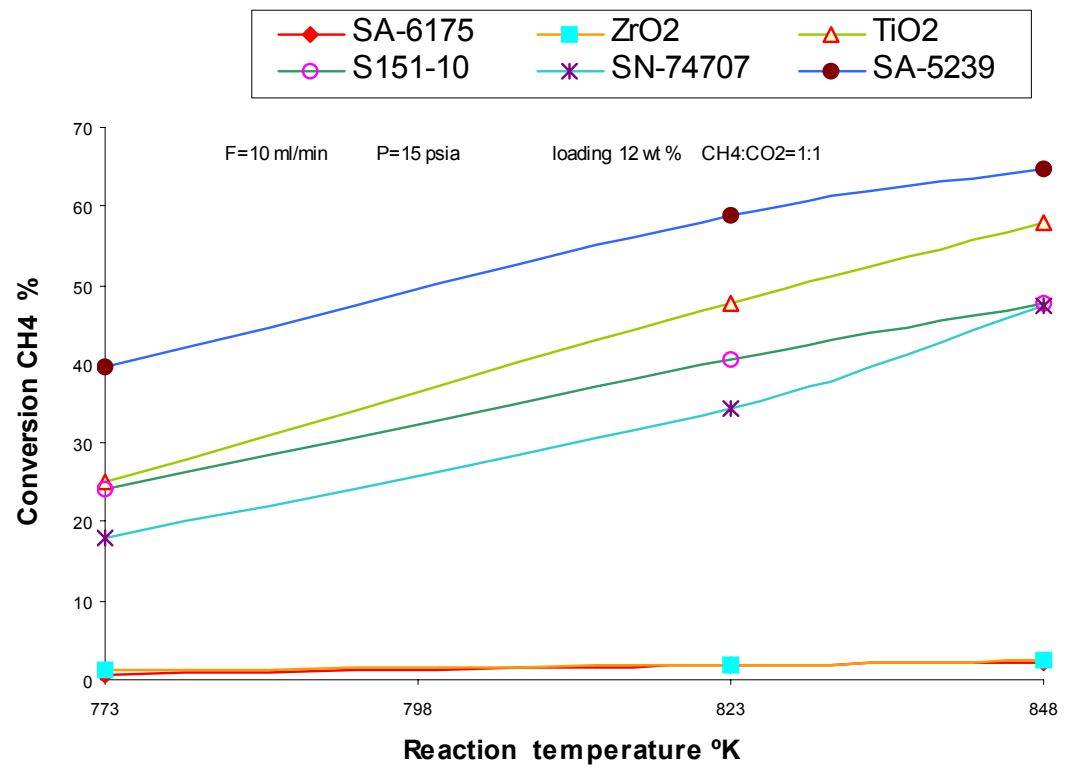

Figure 3. Effect of different types of supports on $\mathrm{CH} 4$ conversion at calcination temperature of $1073^{\circ} \mathrm{K}$ 


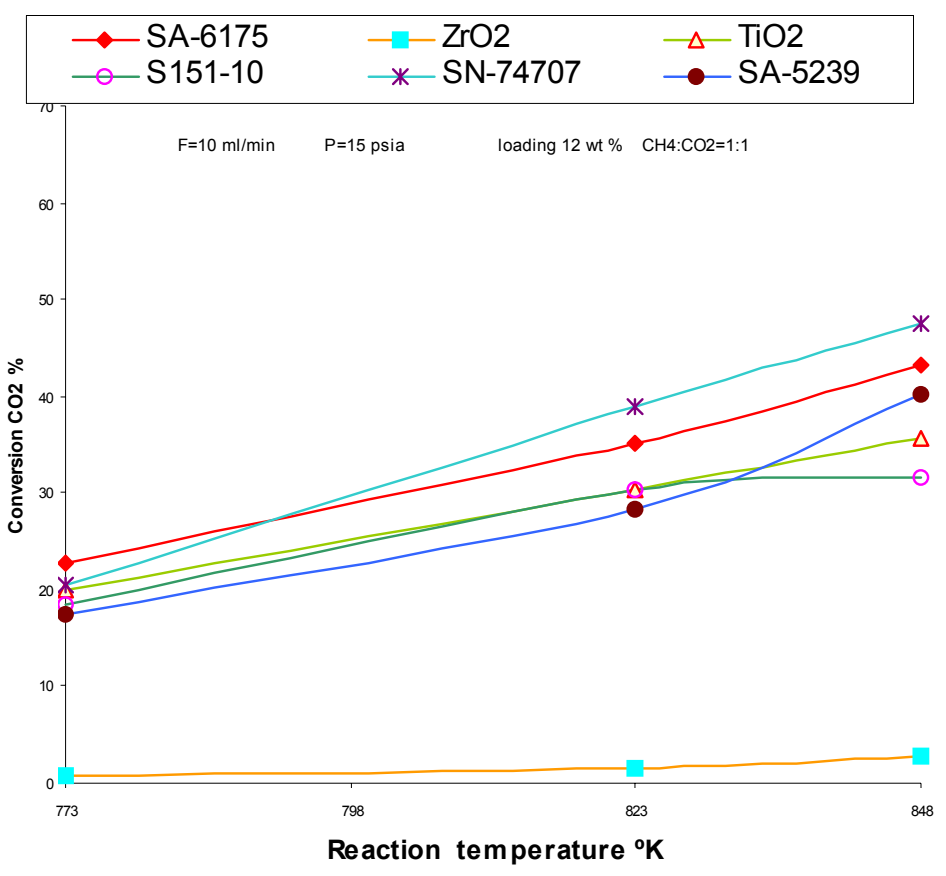

Figure 4. Effect of different types of supports on $\mathrm{CO} 2$ conversion at calcination temperature of

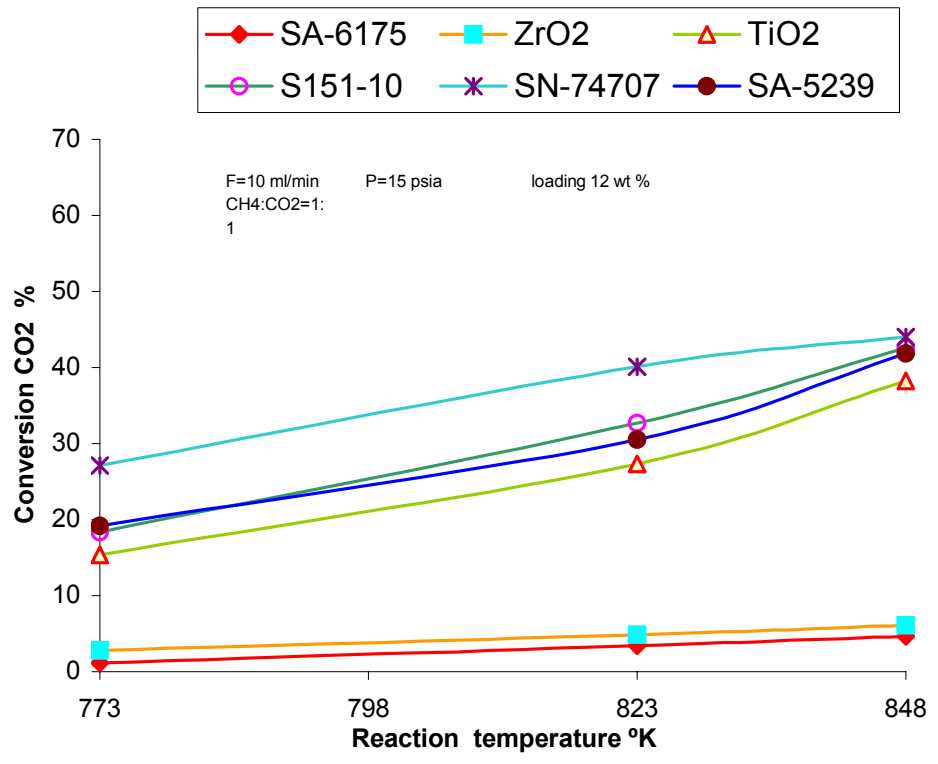

Figure 5. Effect of different types of supports on $\mathrm{CO} 2$ conversion at calcination temperature of $1073{ }^{\circ} \mathrm{K}$ 


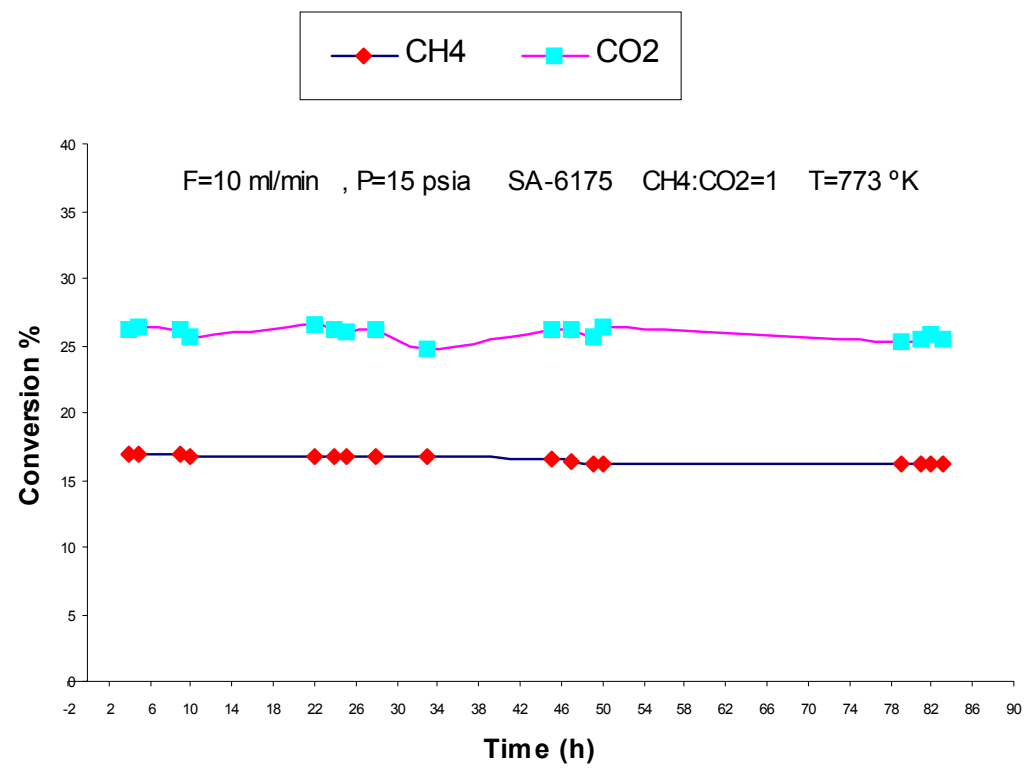

Figure 6. Variation of methane and $\mathrm{CO} 2$ conversion with time for Ni/SA-6175

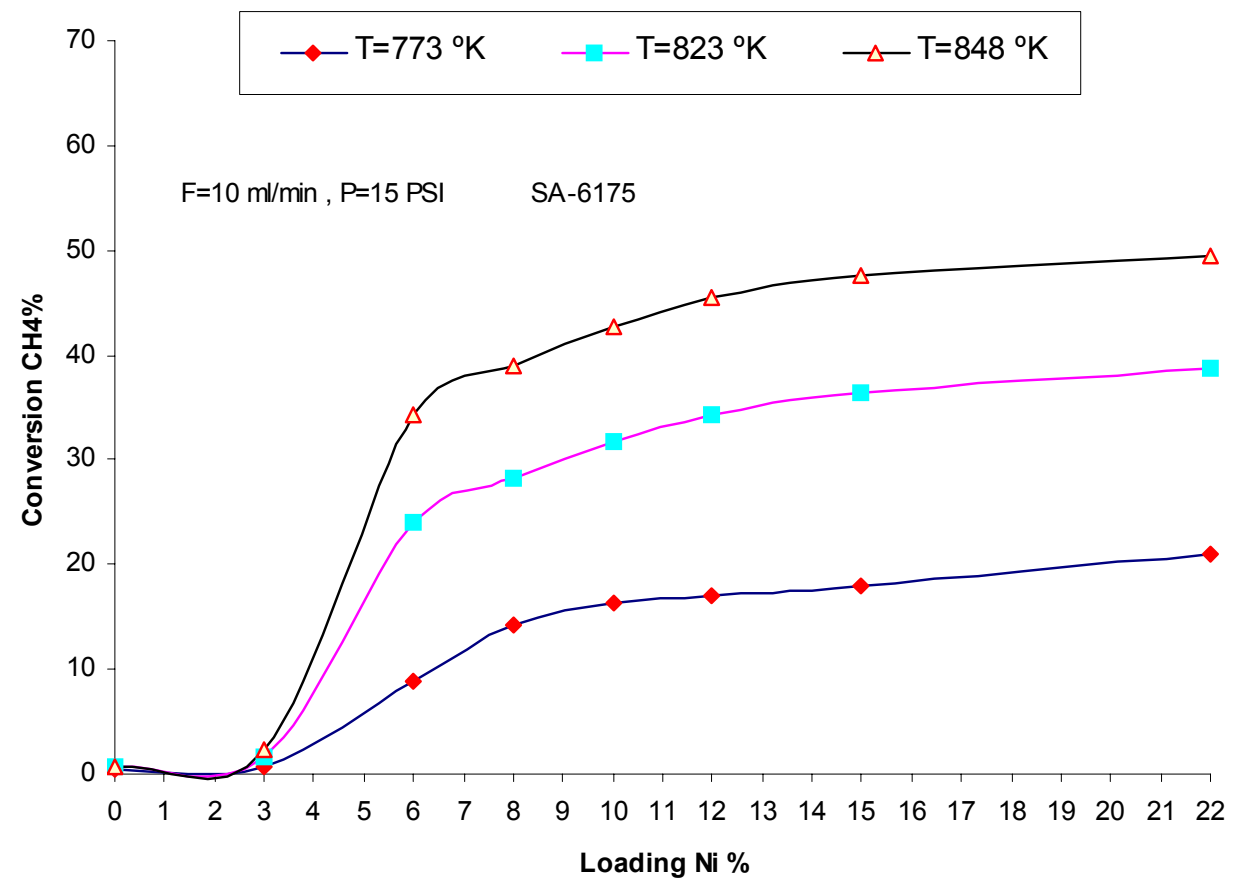

Figure 7. Effect of Ni Loading on $\mathrm{CH} 4$ Conversion 


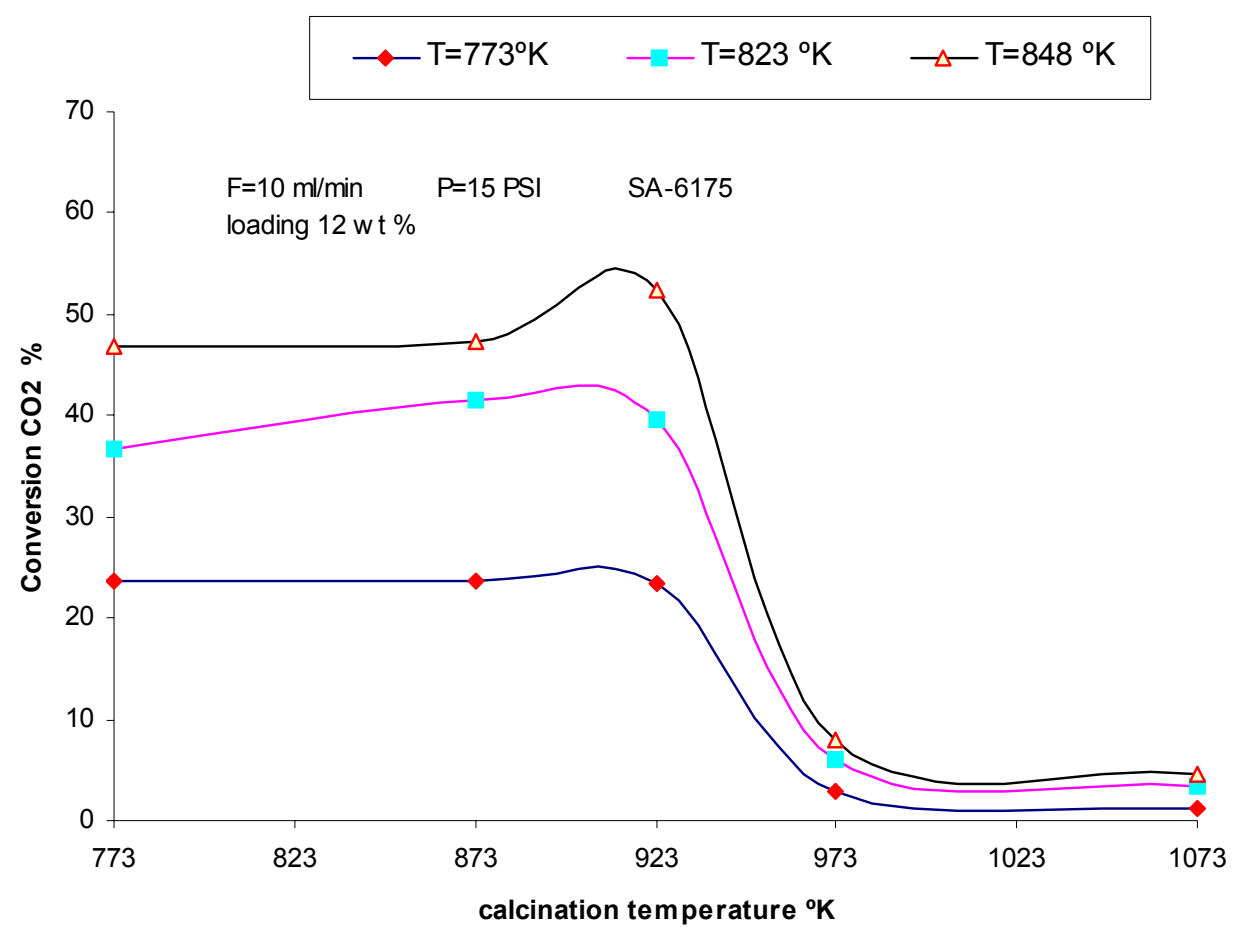

Figure 8. Effect of calcination tem perature on $\mathrm{CO} 2$ conversion 